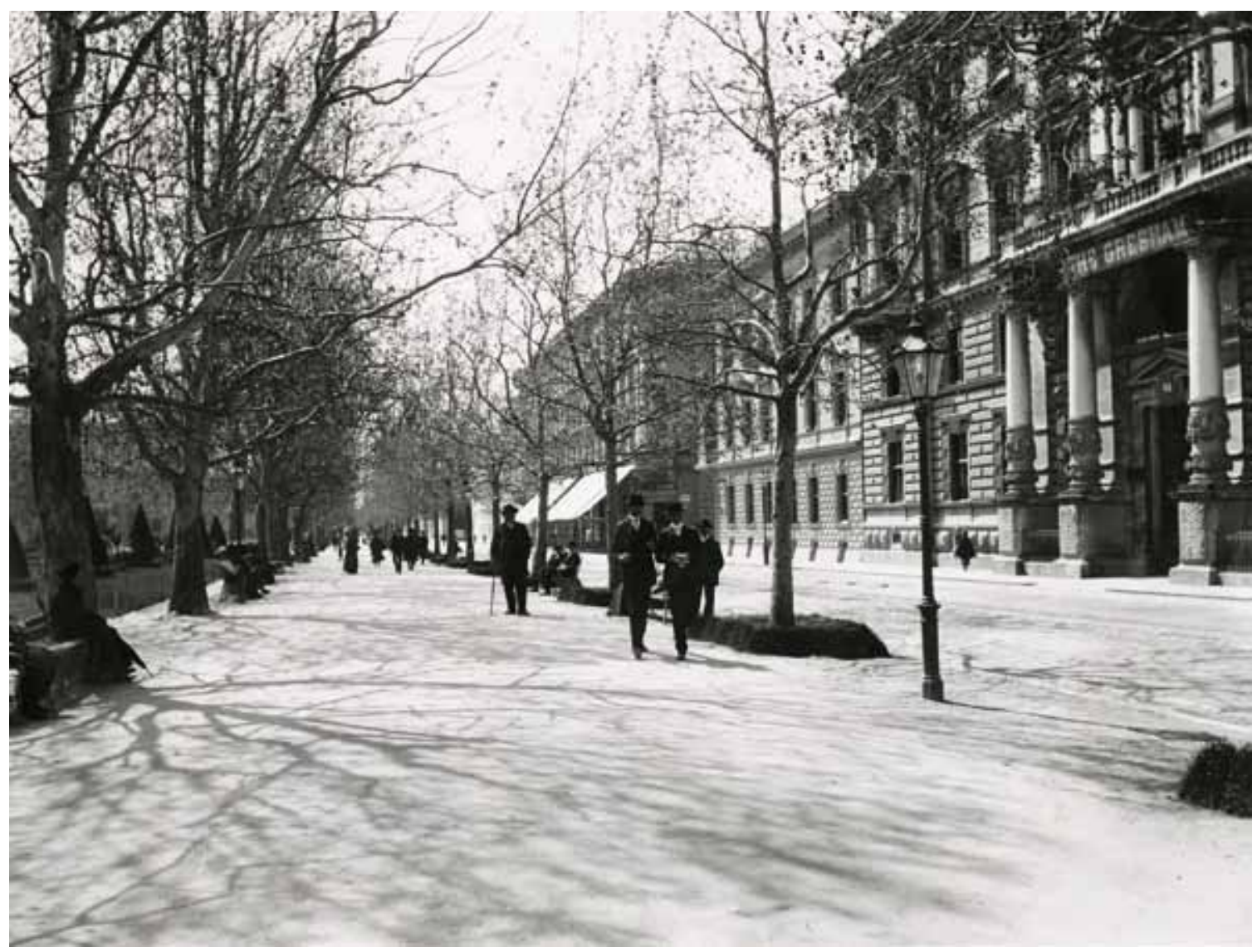

SI. 1: Natpis na palači: The Gresham (Gresham Life Assurance Company) - društvo za životno osiguranje iz Londona, Zrinjski trg 19, prije 1906., MGZ FOT-1306 (Solter 2016: 190). 


\section{I palača i muzej - sve adaptacije palače Vranyczany-Dobrinović na Zrinjevcu 19}

Ana Solter

DOI: $10.17234 / 9789531757232-15$

Arheološki muzej u Zagrebu nalazi se u palači Vranyczany-Dobrinović na Zrinjevcu 19 od 1945. godine. Kroz čitavo stoljeće opstanka prije preseljenja u palaču Muzej nije imao vlastite prostore. Najprije je dijelio zgradu Narodnoga doma s mnogobrojnim drugim institucijama da bi od 1880. godine bio podstanar u prizemlju palače Hrvatske akademije znanosti i umjetnosti. Palača na Zrinjevcu 19 prošla je mnogo vlasnika i funkcija, a samim time i mnogo adaptacija neke uspješnije od drugih, kako bi naposljetku postala zgrada Muzeja.

\section{Palača prije Muzeja}

Iako riječ „palača“ označava raskošnu rezidenciju vladara ili plemića (ponekad reprezentativnu građevinu u kojoj je smještena institucija državne vlasti), palača na Zrinjevcu 19 nikada nije bila dom baruna koji ju je dao graditi. Daje se naslutiti, iz raskošnih prvih arhitektonskih nacrta, da je barun Dragan Vranyczany-Dobrinović ${ }^{1}$ možda u početku i imao tu namjeru, ali kod realizacije izabire „skromniju“ varijantu palače (Bagarić 2013: 145-148; Bagarić 2016: 190-199). Moguće je da se, pak, prije početka gradnje odlučio da mu nije potrebna zagrebačka rezidencija već da će ostati živjeti u Karlovcu te će umjesto toga graditi prvu luksuznu najamnu kuću u Zagrebu. Naime, palača na Zrinjevcu 19 nije svojom svrhom opravdala naziv „palača“ već svojom izvedbom koja ju je, iako nije bila onoliko raskošna koliko su prvi planovi sugerirali, nakon završetka gradnje 1879. godine uvrstila među najljepše i najluksuznije zgrade grada. 0 tome svjedoči novinar Narodnih novina koji je zaintrigiran tajnama što su se skrivale iza luksuznog pročelja, ne mareći na natpis Zabranjen ulaz, na juriš ušao u zgradu te 6. lipnja 1879. godine napisao: „(...) da nepitam za style stare škole, nego da mi godi oku gledati tako krasne detaile od poda do vrha krova, izvedene luxuriozno neštedeć novacah. (...) Dosad nije u Zagrebu bilo ovakve kuće. (...) ali onomu, koji će da tu stanuje, trebat će i debela kesa." ${ }^{2}$ U novosagrađenoj palači Dragan Vranyczany-Dobrinović ustupio je Isidoru Kršnjavome jedanaest soba na prvom katu za priredbu prve umjetničke izložbe tek osnovanog Društva umjetnosti (Maruševski 1986: 101, 111). Kako se zidovi ne bi oštetili, moguće je da je to bila prva izložba načinjena bez upotrebe ijednog čavla i kao da je predodredila daljnju budućnost palače. Zgrada za iznajmljivanje na Zrinjevcu 19 od 1879. do 1916. godine imala je mnogo stanara, ali su nam ostali sačuvani podaci samo o dva: osiguravajuće društvo The Gresham iz Londona ${ }^{3}$ i trgovina klavira Josef Leustek ${ }^{4}$, koji su najvjerojatnije zauzimali prizemlje zgrade, dok je ostatak bio namijenjen privatnim osobama za stanovanje (sl. 1). Sam, pak, barun Vranyczany-Dobrinović za svoje je potrebe uredio trosoban stan u dijelu prvog kata - Bel etage.

\footnotetext{
${ }^{1}$ Barun Dragan Vranyczany-Dobrinović (Karlovac, 10. 10. 1841. - Karlovac, 16. 12. 1910.), gospodarstvenik i veleposjednik u Karlovcu, Zagrebu, Jurovu i Jankovrhu.

$2 * * *$, Zagrebačke crtice, Narodne novine, 6. 9. 1879.

3 „The Gresham“, Agramer Zeitung, br. 27, 3. 2. 1894., 16.

${ }^{4}$ Josef Leustek, Agramer Zeitung, br. 253, 5. 11. 1904., 13.
} 
SI. 2: Kovana rešetka prema narudžbi Radivoja Hafnera: srednji ovalni ukras s konjem - Tomislav Krizman (?), vanjski ukrasi - Alojz Bastl, Zagreb, vjerojatno 1917. (Koprčina 2016: 211).

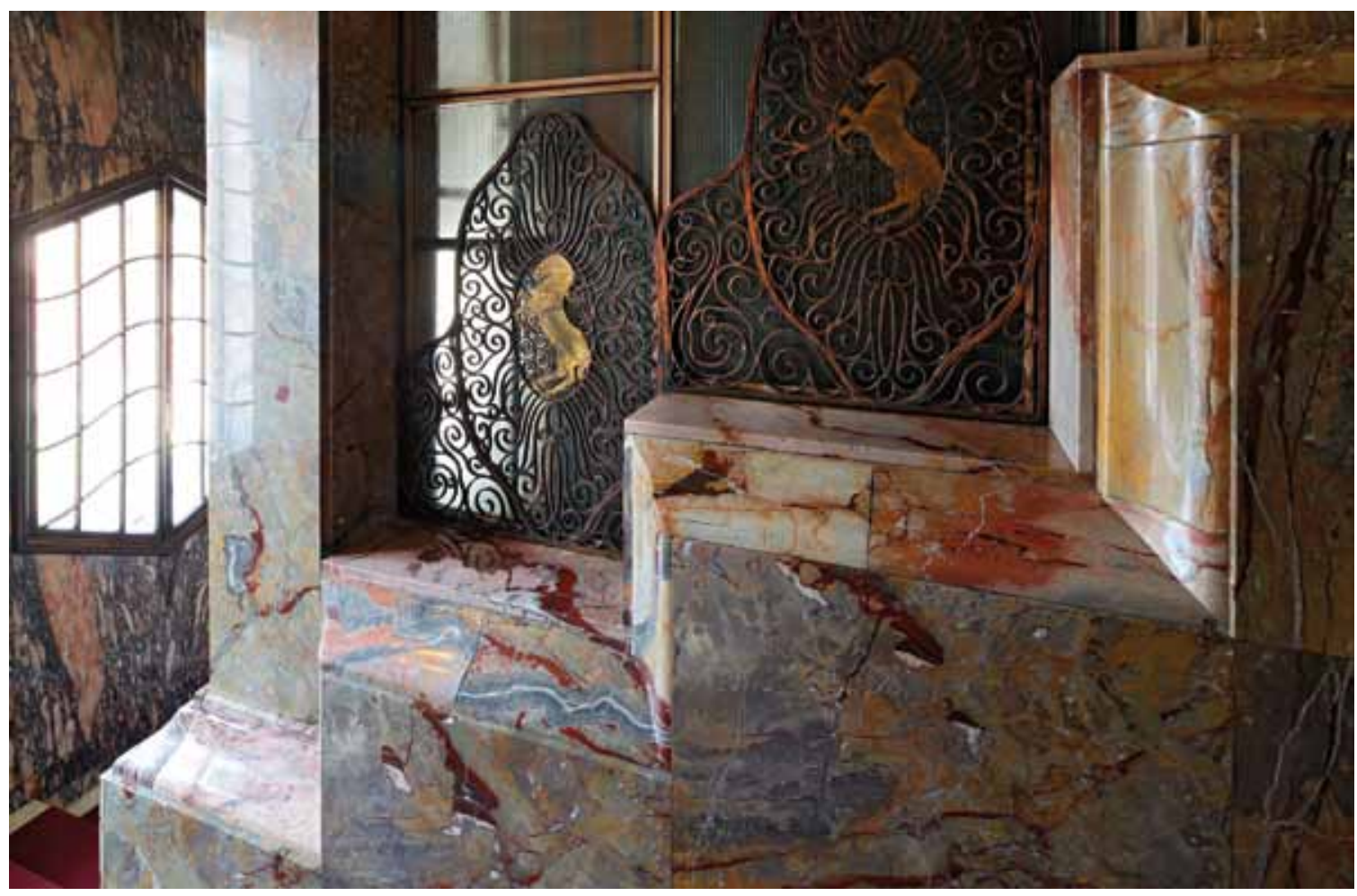

Palaču je od udovice baruna Terezije Vranyczany-Dobrinović za 610.000 kruna kupio 1916. godine Radivoj Hafner ${ }^{5}$, bogati liferant austrougarske vojske konjima i mesom. Od 111 nekretnina prodanih te godine u Zagrebu, palača na Zrinjevcu 19 postigla je najveću vrijednost (Koprčina 2016: 201-219). Novi vlasnik, ubrzo je započeo adaptaciju unutrašnjosti palače. Današnji raskošan izgled dugujemo arhitektu Alojzu Bastlu kojeg je Hafner angažirao 1916. godine za adaptaciju palače i dvorišnih objekata - staje i kolnice koje danas više ne postoje (Koprčina 2016: 205-210). Najveći zahvat Bastlove adaptacije zasigurno je projekt izmicanja stubišta i ugradnja panoramskog dizala zaštićenog željeznom kovanom i pozlaćenom ogradom, ukrašenom monogramom RH i konjima (rad Vjekoslava Bastla i Tomislava Krizmana) (sl. 2). Novo stubište i prizemlje Bastl je dao obložiti mramorom, što nam najbolje prikazuje vrhunac luksuza kojim je adaptacija provedena iako u vrlo teškim vremenima Prvoga svjetskoga rata. Danas mnoga obilježja Bastlove bogate adaptacije nisu ostala sačuvana kao što su reprezentativne drvene oplate pojedinih prostora, namještaj koji detaljima odgovara oplatama, ali i raskošno adaptirane staja i kolnica u dvorištu prema Gajevoj (sl. 3).

Pod, zasad nerazriješenim okolnostima ${ }^{6}$, zgradu je Radivoj Hafner prodao Francusko-srpskoj banci, filijali u Beogradu, koja ju je sporazumno predala u vlasništvo centrale, Francusko-srpske banke u Parizu. Naime, kako bi ju mogla prilagoditi svom djelovanju, banka je započela

\footnotetext{
${ }^{5}$ Radivoj Hafner ( ?, 9. 5. 1874. - Zagreb, 10. 9. 1945.) veleposjednik i trgovac stokom. Hafner je bio strastveni uzgajivač konja i utemeljite uzgoja američkih kasača na ovim prostorima.

${ }^{6}$ Iako se kao razlog najčešće spominje Hafnerov bankrot, za sada nema čvrstih dokaza da je Radivoj Hafner nakon rata izgubio svoje veliko bogatstvo. Dapače, još se u dnevnim novinama u prvim poratnim godinama spominje kao osoba iznimne financijske moći i utjecaja. Miroslav Krleža Hafnera u Dnevniku iz 1918. naziva herojem „koji stvara Historiju za besmrtne stranice Zlatne Knjige Naroda Hrvatskoga“"(Krleža 1977:56).
} 
SI. 3: Blagovaonica Autokluba (Janeković 1932.; MUO-041942).

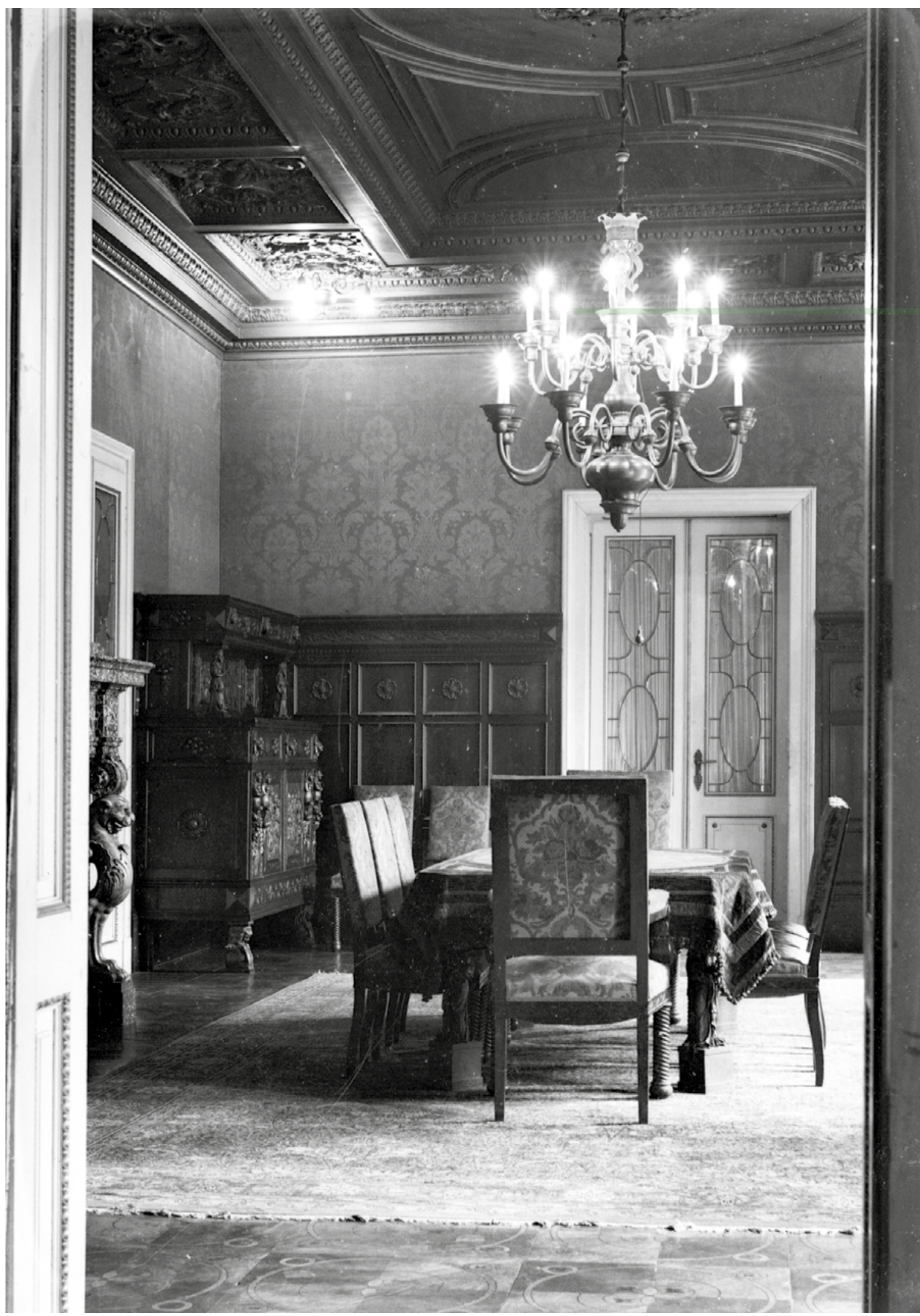




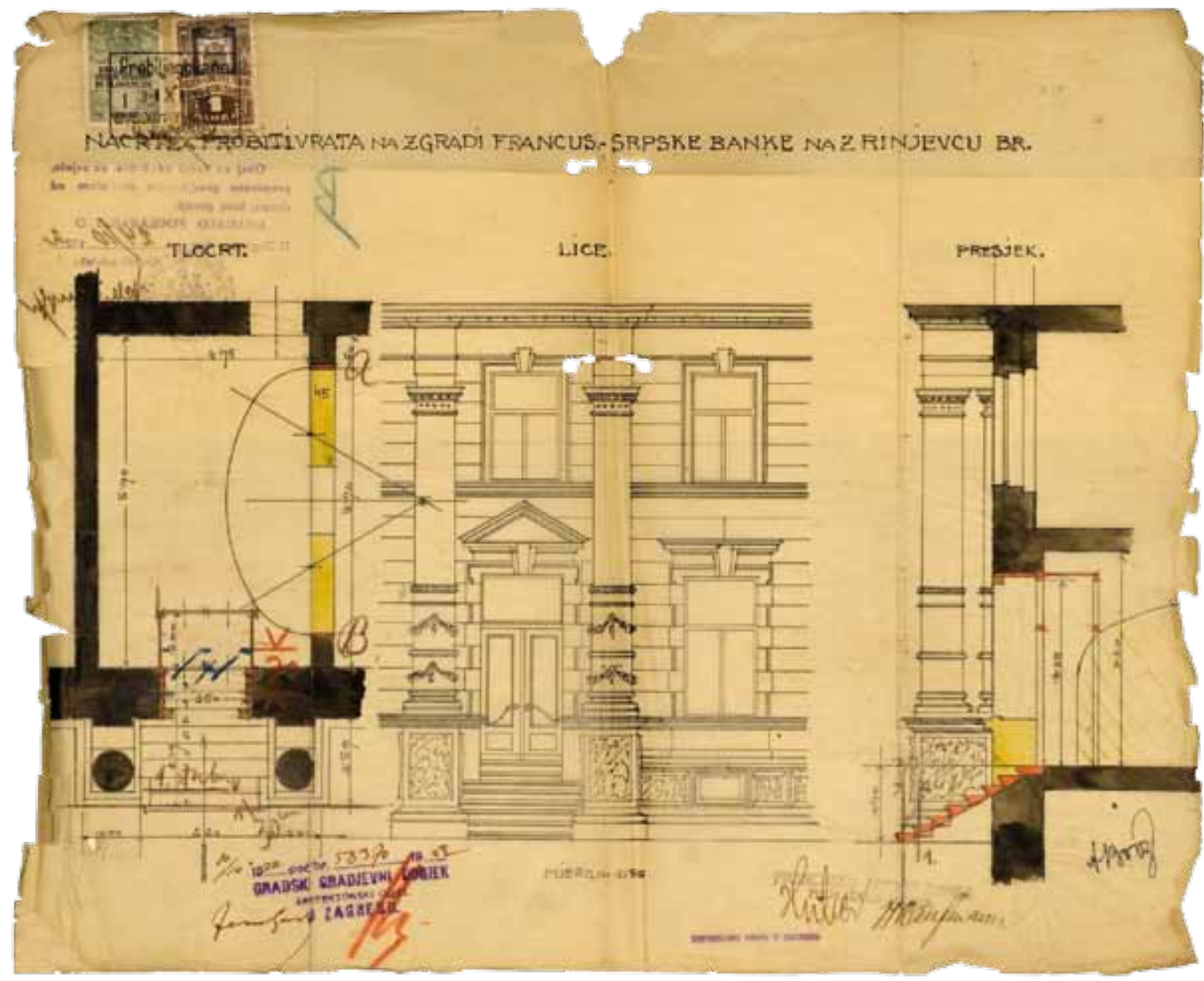

novu adaptaciju zgrade 1919. godine koju je vodio još jedan poznati hrvatski arhitekt, Hugo Ehrlich (Koprčina 2016: 210). Ehrlich nastavlja u Bastlovom stilu s uređenjem ostatka stubišta u mramorne ploče, uređuje poslovni prostor prizemlja te probija nova vrata prema Zrinjevcu (sl. 4). Tijekom prve polovine 1920. godine preuređuje zgradu kolnice u zgradu za stanovanje službenika banke, a 1922. godine luksuznu Hafnerovu staju u uredsku zgradu banke (Koprčina 2016: 211) (sl. 5).

Palaču je od banke 1928. godine kupilo poduzeće Poljoprivredno d.d. u Zagrebu isključivo za najam te se otad u zgradi izmijenjuju mnogi različiti sadržaji: Američki konzulat, Francuski konzulat, Automobilski klub Zagreb, Oficirski klub, Privilegirana agrarna banka, trgovina tehničkih potrepština S. Radan, Diskontna banka d.d. i privatne osobe (sl. 6). U ovom razdoblju dogodile su se samo manje intervencije na zgradi kao što je probijanje još jednog izlaza prema Zrinjevcu na južnoj strani pročelja i pregradnja prizemlja po projektu arhitektonskog ateljea Benedikt \& Baranyai. ${ }^{7}$ Ne znamo točno kada su oba nova izlaza prema Zrinjevcu zatvorena, ali ih više nema na planovima iz 1939. godine kada novim vlasnikom postaju Štedionice Banovine Hrvatske (kasnije Štedionice NDH). Prije početka Drugoga svjetskog rata Štedionica iseljava

${ }^{7}$ HR-DAZG, GPZ, 61571/1931 


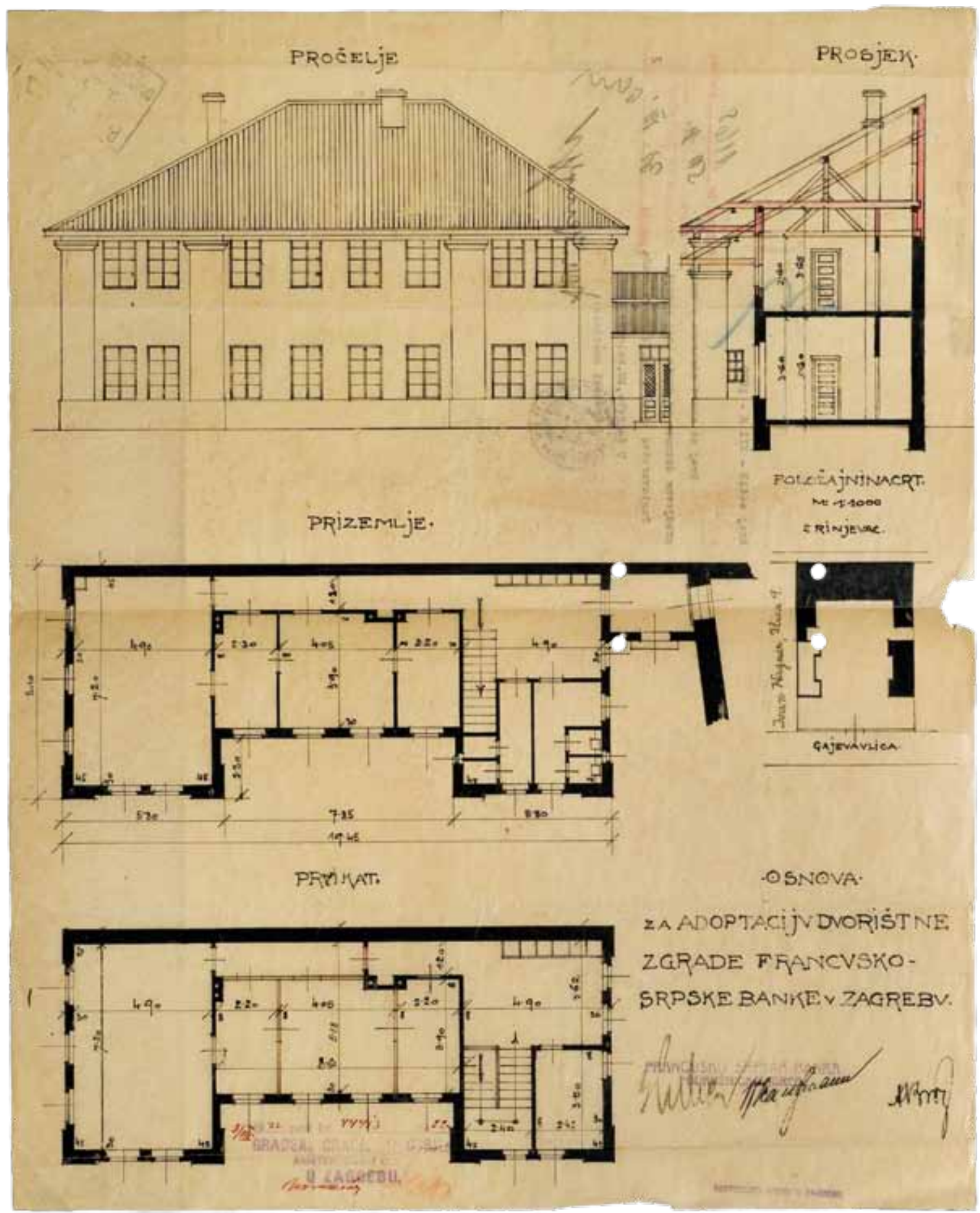

sve stanare iz zgrade, te pristupa drastičnom uređenju palače, čija bi realizacija doprinijela novoj urbanoj vizuri Gajeve ulice. Prema projektu Mladena Kauzlarića srušena su bočna dvorišna krila palače i dvorišne zgrade kako bi se na njihovom mjestu izgradila nova zgrada za trezore (Mirnik \& Rendić-Miočević 2013: 76; Solter 2016: 249, 251-252). Dvorišne zgrade zamijenje- 
SI. 6: Fotografija pročelja palače na Zrinjevcu 19, 1929. - 1931., MGZ FOT-19997 (Koprčina 2016: 208-209).


SI. 7: Rušenje dvorišnih krila, 1941., MGZ FOT-17371 (Koprčina 2016: 213). 
ne su malim podvorničkim stanovima, ali zbog početka rata velika zgrada trezora nije nikada izgrađena. Ipak, da je ta najveća i posljednja adaptacija bila ostvarena znatno bi povećala kapacitet zgrade te palača na Zrinjevcu 19 vjerojatno nikada ne bi pripala Muzeju (sl. 7).

Od 1941. do kraja rata u svibnju 1945. godine u zgradi je smješten glavni stan (komandatura) Wehrmachta na čelu s generalom Edmundom Glaise von Horstenau (Radman-Livaja 2016: 221-223). Za to vrijeme u podrumu se uređuju skloništa protiv avionskih napada, preuređuje se centralno grijanja, ispunjavaju se dimnjaci cementom, a u dvorištu se grade dvije drvene straćare u koje će kasnije zaposlenici Muzeja pohraniti kamene spomenike.

\section{I palača i muzej}

Nakon Drugoga svjetskog rata stvorila se mogućnost za preseljenje Arheološkog muzeja u Zagrebu iz Palače Akademije u neku novu zgradu. Tadašnji ravnatelj Mirko Šeper, najprije, je predložio za novu muzejsku zgradu bivši "Seljački dom" (danas zgrada Moderne galerije) i zgradu Državne radne službe na križanju Savske i Varaždinske ceste (danas Vukovarska ulica). Tek kao opcije drugog reda predložio je zgradu nekadašnje Privilegirane agrarne banke na Zrinskom trgu 7 (danas zgrada Ministarstva vanjskih i europskih poslova), palaču Odescalchi u Martićevoj ulici 14 i palaču Vranyczany-Dobrinović na Zrinjevcu 19 (Solter 2016: 228).

Odobrenje za useljenje u palaču na Zrinjevcu 19 pristiglo je 31. svibnja 1945. godine ${ }^{8}$, svega četiri dana nakon Šeperovih molbi (Ilčić \& Mirnik 2008: 366). Mirko Šeper ubrzo je smijenjen, a na ravnateljsko mjesto vraćen je za vrijeme rata umirovljeni ravnatelj Viktor Hoffiller koji je, uz pomoć dviju mladih kustosica Ivice Degmedžić i Ksenije Gasparini, preparatora Jakova Pavelića i dva podvornika Nikole Kasuna i Stjepana Miholića, preselio cijeli Muzej. Ministarstvo prosvjete Kulturno-umjetničkog odjela naredilo je da se Muzej preseli u nove prostorije u najkraćem mogućem roku, te da improvizira izlaganje predmeta prema mogućnostima s kojima momentalno raspolaže ne računajući, zasad, na nikakve pregradnje u zgradi ili nabavku vitrina. ${ }^{9}$ Arheološki muzej u Zagrebu dobio je za svoje zbirke, kancelarije, biblioteku i sve potrebne prostorije zgradu na Zrinjevcu 19 pod uvjetom, da se u istu zgradu preseli u potpunosti i Arheološki zavod Sveučilišta u Zagrebu. Prostorije Arheološkog zavoda u Boškovićevoj ul. 3 dodijeljene su u cijelosti Historijskom muzeju pod uvjetom da u njih preseli zajedno sa svojim inventarom i kancelarijom i inventar bivšega Ratnog muzeja u Zagrebu, te da nastavi sa skupljanjem materijala za muzej Narodnog Oslobođenja. ${ }^{10}$ Međutim, dok je Muzej primao naredbe od Ministarstva u zgradu na Zrinjevcu 19 u međuvremenu je uselila Komanda narodne milicije Okružnog narodnooslobodilačkog odbora Zagreb te nije iselila čak i nakon što je rasformiran 27. prosinca 1945. godine. Napustila je palaču tek početkom 1946. godine kada je započelo raskuživanje od stjenica i buha.

Hoffiller, ionako, nije smatrao zgradu prikladnom za smještanje muzejskih zbirki ponajprije jer nije bila sigurna od provale (samo u drugoj polovini 1945. godine bilo ih je deset). Kao najveći problem za sigurnost navodi da zgrada ima više širokih ulaza - što je bilo teško osigurati bez dodatnog troška kupovine željeznih vrata. Sigurnost zgrade bila je dodatno narušena, iz današnje perspektive apsurdnim naredbama, da se u palaču primaju strane osobe na spavanje. Praksa je bila takva sve do listopada 1945. kada su sudionici kongresa Srba u Hrvatskoj u zgradi ostavili veliki nered i poplavili prizemlje. ${ }^{11}$

${ }^{8}$ AAMZ 189, Dokumentacija o zgradi, Dopis v. d. načelnika Grge Gamulina od 31. 5. 1945., 9/45.

9 AAMZ 189, Dokumentacija o zgradi, Dopis v. d. načelnika Grge Gamulina od 21. 7. 1945., 73/45.

10 AAMZ 189, Dokumentacija o zgradi, Dopis v. d. načelnika Grge Gamulina od 11. 8. 1945., 105/45.

11 AAMZ 189, Dokumentacija o zgradi, Dopis V. Hoffillera Stanarskom uredu od 8. 10. 1945., 182/45. 
Dodatne probleme stvaralo je mišljenje stručnjaka Ministarstva građevina da je nosivost pojedinih katova, dapače i prizemlja, vrlo slaba - tek $350 \mathrm{~kg} / \mathrm{m}^{2}$. U dokumentaciji ${ }^{12}$ je navedeno da se spomenici težine do $600 \mathrm{~kg} / \mathrm{m}^{2}$ jedino mogu postaviti uz zidove, dok se teži spomenici moraju smjestiti u dvorište. Hoffiller to oštro odbija zbog hladnih zagrebačkih zima, koje bi bez adekvatne zaštite već u jednoj zimi velike kamene spomenike uništile bez povratka. Građevinska inspekcija predlaže da se dio spomenika izloži uza zid u veži, nakon što se ploče na kojima bi stajali ispune betonom, te da se u podrumu ugrade betonski stupovi i pojačaju zidovi, kako bi se barem u prizemlju mogli smjestiti kameni spomenici do $2000 \mathrm{~kg} / \mathrm{m}^{2}$. Viktor Hoffiller iznerviran cijelom situacijom piše: „Ali s druge strane priznajem, da mi nova zgrada ne čini veselja, pa mi neprestano zuje u ušima riječi g. pomoćnika Ministra finansija: ‘Ako imate gdje biti, ostanite tamo gdje jeste. $)^{\text {"13 }}$

Kako bi zgrada bila spremna za preseljenje Muzeja započelo se s raspodjelom uredskog namještaja preostalog nakon iseljenja njemačkog generalštaba. Naredbom ministarstva prosvjete Kulturno-umjetničkog odjela ${ }^{14}$ namještaj je podijeljen raznim zagrebačkim institucijama: Etnografskom muzeju ${ }^{15}$, Muzeju za umjetnost i obrt ${ }^{16}$, Konzervatorskom zavodu ${ }^{17}$, Arheološkom muzeju ${ }^{18}$, Historijskom muzeju ${ }^{19}$ i Ministarstvu prosvjete Kulturno-umjetničkom odjelu ${ }^{20}$.

Palača Vranyczany-Dobrinović je 1945. godine bila u vlasništvu bivše Štedionice Nezavisne Države Hrvatske. Banka je nakon rata bila u likvidaciji, koju je obavljala Zemaljska banka za Hrvatsku u Zagrebu. ${ }^{21}$ Štedionica NDH, bez obzira na odluku Ministarstva, potraživala je, kao vlasnik, povrat cjelokupnog namještaja. Viktor Hoffiller na taj zahtjev odgovara: „Taj namještaj sigurno ne potječe sav od banke, sigurno je i njemačka vojska mnogo toga donijela, jer su tamo bili uredi

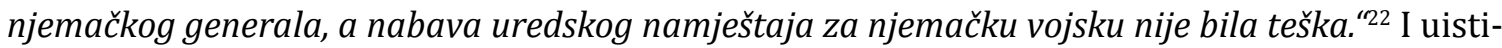
nu, godinu dana kasnije povrat imovine od Arheološkog muzeja tražit će privatne osobe Paula Auš (ormar) i Štefa Vinski (perzijski tepih) kojima je imovina bila otuđena za vrijeme NDH te završila na korištenje štabu njemačkog generala. ${ }^{23}$ Dodatno je Štedionica NDH od Muzeja tražila da stupi u najamni odnos i potpišu najamni ugovor jer je zgrada privatno vlasništvo Banke. ${ }^{24}$

\footnotetext{
12 AAMZ 189, Dokumentacija o zgradi, Zapisnik komisije Ministarstva graditeljstva od 12. 8. 1945., 189/45.

13 AAMZ 189, Dokumentacija o zgradi, Dopis Viktora Hoffillera Ministarstvu prosvjete od 31. 10. 1945., 189/45.

14 AAMZ 189, Dokumentacija o zgradi, Dopisi v. d. načelnika Grge Gamulina od 28. 7. 1945., 115/45 i od 18. 8. 1945., $118 / 45$.

15 Etnografskom muzeju ustupilo se: 4 pisaća stola, 5 stolica, 1 stolna lampa, 2 police, 2 stakla, 1 rolo ormar, 2 telefona.

16 Muzeju za umjetnost i obrt ustupilo se: 6 pisaćih stolova, 6 stolica, 8 fotelja,3 željezne kase, 1 polica, 2 ormara, 4 stolića za pisaću mašinu, 2 stajaće lampe, 2 ormarića za kartoteku, 1 rolo ormarić, 1 košarica za papir.

17 Konzervatorskom zavoda ustupilo se: 9 pisaćih stolova, 12 običnih stolaca, 3 stolića za mašinu, 7 ormara, 1 stolić za telefon, 3 košare za papir, 4 stolne svjetiljke, 2 vješalice, 1 zidna lampa, 3 stola, 1 sag, 1 regal, 1 polica, 1 rolo ormar, 1 okvir za kauč, 1 željezna blagajna, 1 željezni ormar,1 kutija za kartoteku, 3 stolića, 1 lavor, 1 amper, 1 zavjese.

18 Arheološkom muzeju ustupilo se: 15 ormara, 7 pisaćih stolova, 7 stolića za mašinu, 15 lampa, 25 stolica, 3 telefonska stolića, 2 vješalice, 5 željeznih kasa, 3 lustera, 6 običnih stolova, 2 košare za smeće, 11 fotelja, 1 garnitura od 12 stolica, 2 stelaže, 8 pari zastora, 2 karniše, 1 ugaona tapecirana klupa, 1 ploča za stol, 1 daska za crtanje, 1 vitrina, 1 rolo ormar, 1 manipulacioni stol, 1 divan,1 okrugli stolić, 1 rezbarena klupa, 2 uljene slike, 2 ćilima, 1 pribor za pisanje, tintarnica, sušilo, mapa, tasa, 12 telefona, 1 perforator, 1 kutija za spise, 1 rama, 2 okrugla stolića, 1 ljestve, 2 ormarića za metle, 3 kefe za pod, 1 električna peć.

${ }^{19}$ Historijskom muzeju ustupilo se: 1 manipulacioni stol, 9 stolića za mašinu, 1 željezna blagajna, 9 stolaca, 5 pisaćih stolova, 5 fotelja, 6 ormara, 1 stolić za telefon, 1 manipulacioni stol, 1 stolić za šah, 1 svjetiljka, 1 vješalica, stelaža, 1 ćilim.

20 Ministarstvu prosvjete Kulturno-umjetničkom odjelu ustupilo se: 5 naslonjača, 2 naslonjača, jedan stolić.

21 AAMZ 112, 94/1946.

22 AAMZ 189, Dokumentacija o zgradi, Dopis Viktora Hoffillera Ministarstvu prosvjete od 20. 11. 1945., 243/45.

23 Oduzimanje židovske imovine u Zagrebu započelo je odmah po proglašenju Nezavisne Države Hrvatske, koja će ubrzo, u vezi s tim, izdati cijeli niz zakonskih odredbi (Brandl 2016: 95-97).

24 AAMZ 189, Dokumentacija o zgradi, Dopis Štedionice NDH Arheološkom muzeju od 25. 8. 1945., 134/45.
} 


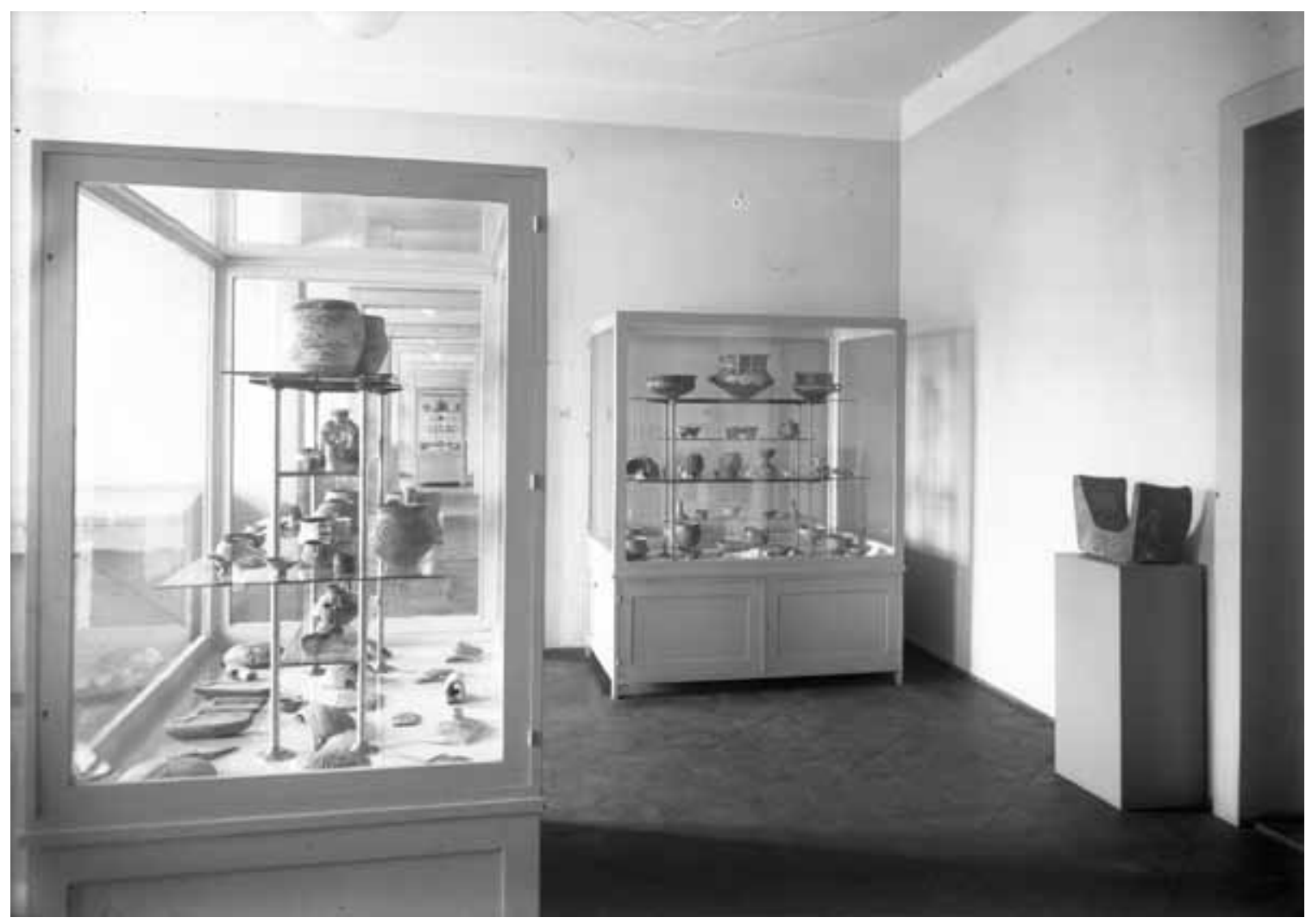

Kako bi se opravdao veliki trošak najma, koji traži Štedionica, u istu zgradu zajedno s Arheološkim muzejom sele i Povijesni muzej i Muzej narodnooslobodilačke borbe te Sveučilišni zavod za arheologiju i Sveučilišni zavod za povijest umjetnosti i kulture s Grafičkom zbirkom. Preseljenje Arheološkog muzeja trajalo je godinu dana (u zgradi Akademije ostali su samo veći kameni spomenici, koji nisu mogli biti prebačeni zbog težine, i numizmatička zbirka, za koju nisu bili zadovoljeni sigurnosni uvjeti unutar nove zgrade na Zrinjevcu 19). Od 1946. godine vrijedio je ugovor sa Štedionicom NDH po kojem su tri muzeja, Arheološki, Povijesni i Muzej NOB-a, morala plaćati ukupnu godišnju najamninu od 180.000 dinara, a prostor palače podijeljen je, barem na papiru, na tri jednaka dijela. ${ }^{25}$ Muzej NOB-a i Povijesni muzej zbog tehničkih razloga nisu mogli koristiti sve pripadajuće prostorije, stoga su svi prostori palače do daljnjega bili dodijeljeni Arheološkome muzeju na korištenje. Iako je cijela zgrada stavljena na raspolaganje Arheološkome muzeju, sredinom 1946. godine, nakon što je Okružni NO u potpunosti iselio iz dvorišta zgrade, u isto dvorište prema Gajevoj ulici uselilo je poduzeće „Jugoauto“ cijeli automobilski park s radionicama što je privremeno zaustavilo preseljenje kamenih spomenika, koji su trebali biti smješteni u barake u dvorištu. ${ }^{26}$ Preseljenje ostalih kamenih spomenika (njih 1000) započelo je u zimu 1946. godine kada se dvorište konačno ispraznilo. Zgrada je 1947. godine proglašena državnim vlasništvom te je Arheološki muzej u Zagrebu uknjižen kao vlasnik, tj. zgrada je postala opća narodna imovina pod upravom Muzeja (Solter 2016: 227).

25 HR HDA-291 MNP NRH, 27251/1946.

${ }^{26}$ AAMZ 189, Dokumentacija o zgradi, Dopis Viktora Hoffillera Ministarstvu prosvjete od 20. 8. 1946., 405/46. 
SI. 9: Stalni postav Arheološkog muzeja u Zagrebu, 1955. (AAMZ 73).
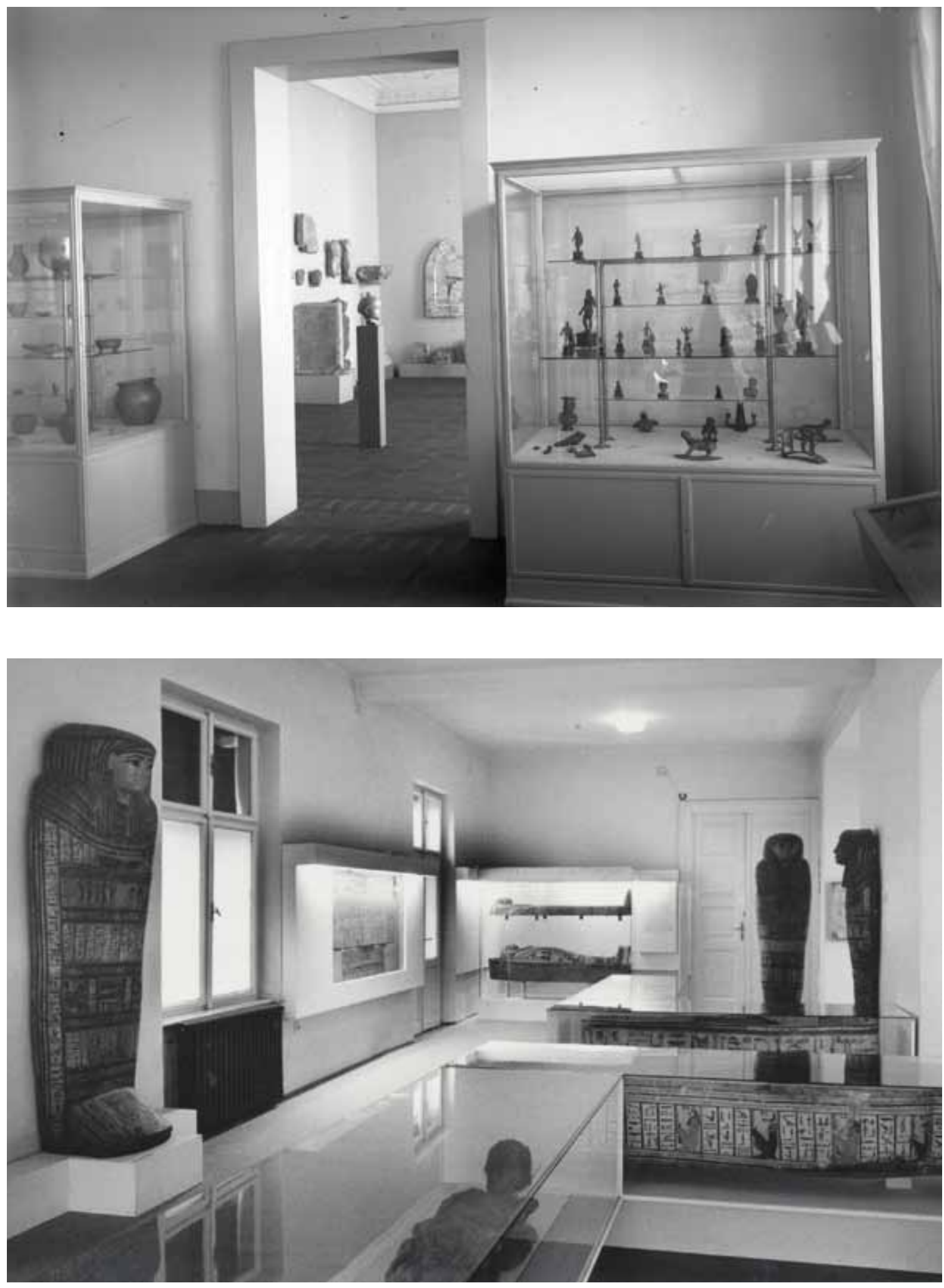

SI. 10: Stalni postav Egipatske zbirke, 1974. (M. Grčević, AMZ i-478). 


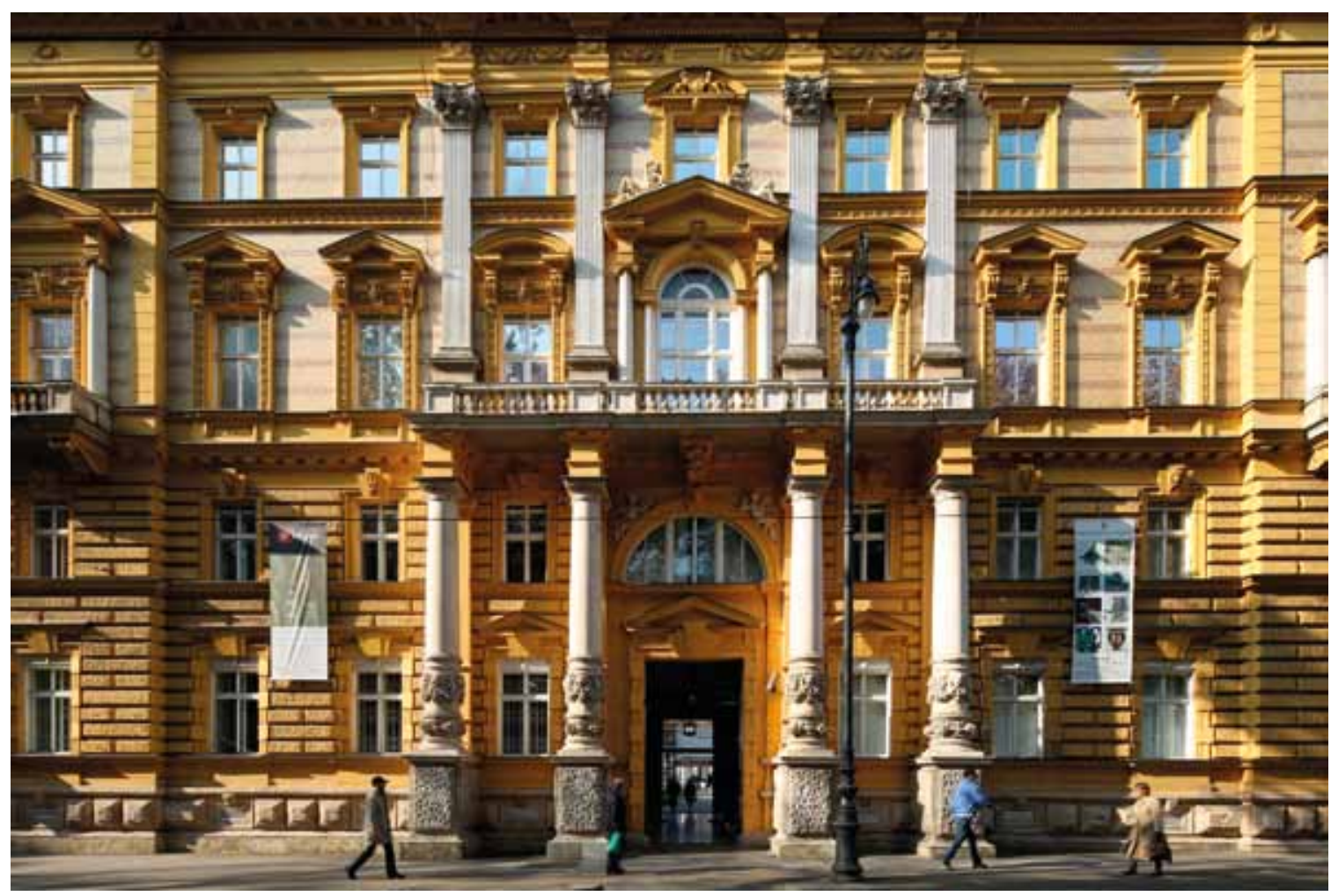

Nakon preseljenja 1945. godine Muzej je u vrlo kratkom roku čak šest puta mijenjao izgled stalnog postava (sl. 8 i 9). Prvi stalni postav, doduše skroman izgledom, bez velikih financijskih ulaganja, otvoren je za posjetitelje već 1 . svibnja 1946. godine, samo godinu dana nakon prve naredbe o preseljenju (Solter 2016: 232). Kako stambeni interijer palače nije bio adekvatan za postavljanje muzejskih izložaka, ubrzo su nakon prvog stalnog postava skinuta sva vrata na drugome katu, odstranjeni su izvorna hrastova oplata, mramorni kamini te lusteri, kao i sve preostalo pokućstvo (Mirnik 2009: 297). Od Vranyczanyjeva interijera ostali su samo parketni podovi, koji će biti odstranjeni u adaptaciji 90-ih godina, i štukaturni stropovi. Potkrovlje zgrade služilo je kao depozitorij, kao i veći dio podruma.

Međutim, tek početkom 1969. započinju prve velike građevinske adaptacije palače u muzejske svrhe. Tada je kompletno renoviran treći kat kako bi se stvorili uvjeti za novi stalni postav pretpovijesne i egipatske zbirke koji je otvoren za publiku 1974. godine (Vinski-Gasparini, Gorenc 1974:135-139) (sl. 10).

Krajem osamdesetih nastavlja se obnova muzejske zgrade te je 1989. godine započela sanacija krova koja je trajala četiri mjeseca. Nakon toga uslijedila je obnova fasade te je 1991. godine ona poprimila svoju prepoznatljivu žutu boju za koju se komisija Zavoda za zaštitu spomenika Ministarstva kulture jednoglasno složila da je neprimjerena te da je agresivnost boje teško narušila profinjeni koloristički sklad Zrinjevca (Solter 2016: 263-265). U rujnu 2011. godine, i opet 2013., izvedena su istražna sondiranja na istočnom pročelju palače kojima je ustanovljena izvorna oker boja pročelja koja nije bila monokromatska. Prvotna je koloristična slika pročelja ipak naglašavala istaknute profile nešto svjetlijom bojom od one upuštenih dijelova i plašta zida (sl. 11). 
Najveći adaptacijski postupci na unutrašnjosti zgrade, prema projektu Duška Dropulića, počinju krajem 1995. godine, kada dolazi do kompletnog razmještaja sadržaja unutar Muzeja. Najprije je uređeno potkrovlje palače gdje se otad nalaze uredske prostorije, što je omogućilo da se čitav prvi kat kompletno uredi kao izložbeni prostor za povremene izložbe. U drugoj fazi obnove 1997. godine uređeni su podrum, prizemlje i sva tri kata izložbenog prostora. Adaptacija drugih prostora (ulaz u Muzej, ulaz na pojedine katove, „svečana soba“) kao i izložbenih postava, ostvarena je po projektu arhitekta Marija Beusana (Rendić-Miočević 2009: 35). U povodu otvorenja obnovljene zgrade 16.11.1999. godine, postavljen je privremeni stalni postav na tri kata Muzeja, prvi put nakon što je postav rasformiran zbog ratnih okolnosti. Rad na novom stalnom postavu započeo je 2000. godine, no ovaj put bez većih adaptacija u samom prostoru palače. Prvi dio, stalni postav pretpovijesne zbirke, otvoren je 2003. godine, a posljednji segment, postav srednjovjekovne zbirke, u siječnju 2017. godine (sl. 12).

Palača na Zrinjevcu 19. kroz stoljeće i pol promijenila je mnogo vlasnika, koji su unosili novi sadržaj i time mijenjali izgled palače i vrta prema Gajevoj ulici. Najveće adaptacije su bile djelo velikih arhitekata, sve su bile rađene smisleno, no, ipak, nekih se danas sjećamo sa sramom. Međutim, sve su bile potrebne kako bi nastavile životni vijek palače koja bez svrhe i stanara nema šanse za preživljavanjem.

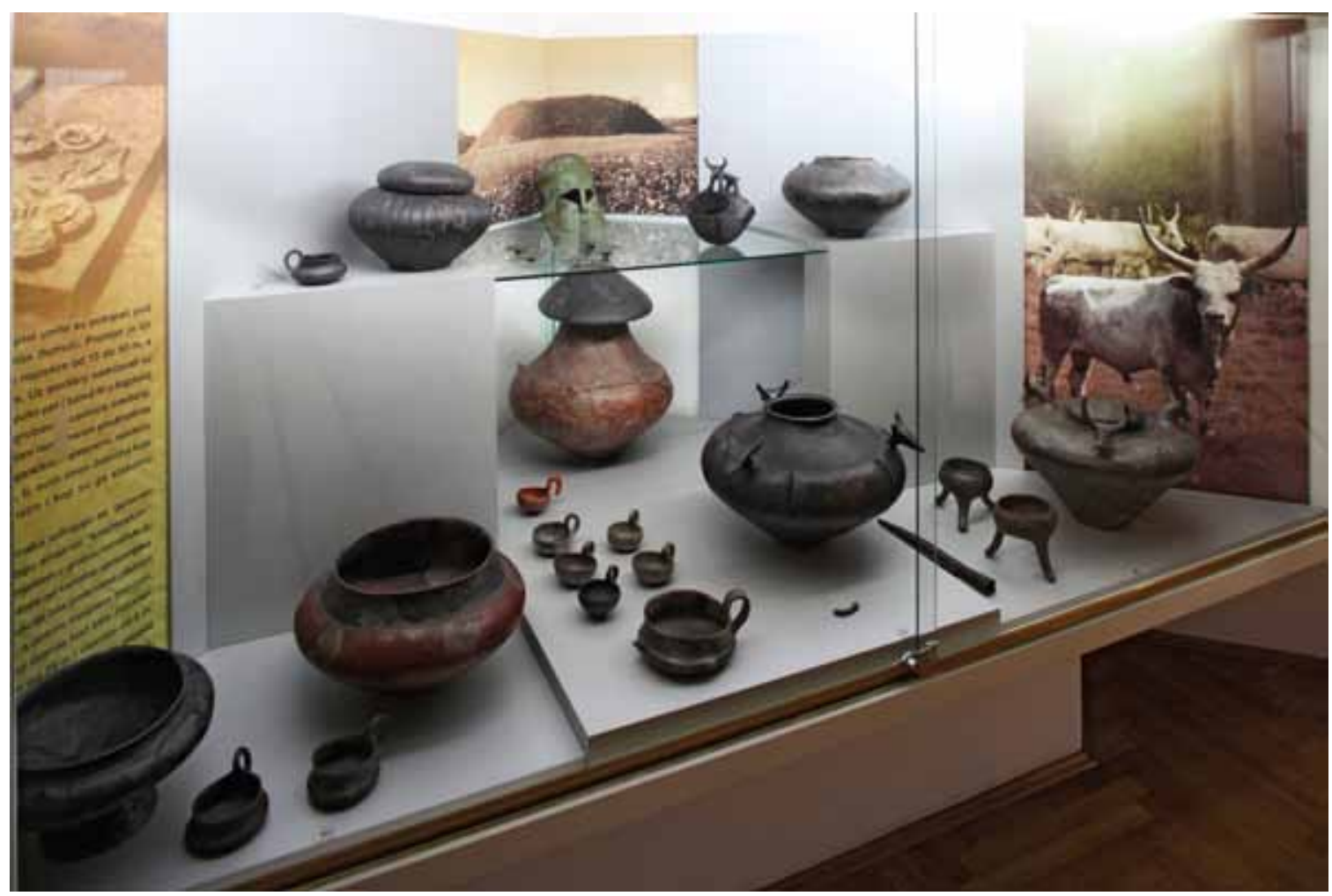

SI. 12. Prilikom postavljanja novog stalnog postava Pretpovijesne zbirke korištene su originalne vitrine arhitekta Stjepana Planića iz 1974. godine (fotografirao: D. Fabijanić). 


\section{Literatura}

Bagarić M. 2013. Arhitekt Otto von Hofer i plemićka obitelj Vranyczany-Dobrinović. Radovi Instituta za povijest umjetnosti, 37. Zagreb. 145-158.

Bagarić, M. 2016. Palača baruna Dragana Vranyczany-Dobrinovića. U: Arheološki muzej u Zagrebu - život od 19. do 21. stoljeća (ur. Ana Solter). 190-199.

Brandl, N. M. 2016. Židovska topografija Zagreba kojeg više nema. Historijski zbornik LXIX. 91103.

Iličić, E., Mirnik, I. 2008. Povijest palače Arheološkog muzeja u vremenu od njegove izgradnje do 1954. godine. Vjesnik Arheološkoga muzeja u Zagrebu, 3. s., XLI. 343-376.

Krleža, M. 1977a. Dnevnik 1918-22: Davni dani II.

Koprčina, A. 2016. Radivoj Hafner, drugi vlasnik palače na Zrinjskom trgu 19 i reprezentativno preuređenje arhitekata Bastla i Ehrlicha. U: Arheološki muzej u Zagrebu - život od 19. do 21. stoljeća (ur. A. Solter), 2016, 200-219.

Maruševski, O. 1986. Iso Kršnjavi kao graditelj. Društvo povjesničara umjetnosti SR Hrvatske, Zagreb.

Mirnik, I. 2009. Arheološki muzej u Zagrebu. U: Hrvatska arheologija u XX. stoljeću (ur. J. Balen, B. Čečuk). Zagreb. 289-320.

Mirnik, I. \& Rendić-Miočević, A. 2013. Arheološki muzej u Zagrebu. U: Zbornik radova 2. kongresa hrvatskih muzealaca, Muzeji i arhitektura u Hrvatskoj (ur. J. Galjer). Zagreb. 73-79.

Rendić-Miočević, A. 2009. Arheološki muzej u Zagrebu. Vijesti muzealaca i konzervatora 1-4, 28-45.

Solter, A. 2013. Arheološki muzej u Zagrebu - neostvareni projekti. U: Zbornik radova 2. kongresa hrvatskih muzealaca, Muzeji i arhitektura u Hrvatskoj (ur. J. Galjer). Zagreb. 214-218.

Solter, A. 2016. Arheološki muzej u Zagrebu - život od 19. do 21. stoljeća. Arheološki muzej u Zagrebu. Zagreb.

Vinski-Gasparini, K., Gorenc, M. 1974. U povodu novog postava prethistorijske i egipatske zbirke Arheološkog muzeja u Zagrebu. Vjesnik Arheološkog muzeja u Zagrebu, 3. s., VIII. 135-139.

\section{Arhivski fondovi}

Arhiv Arheološkog muzeja u Zagrebu (AAMZ)

Državni arhiv u Zagrebu (HR-DAZG)

Hrvatski državni arhiv u Zagrebu (HR HDA) 